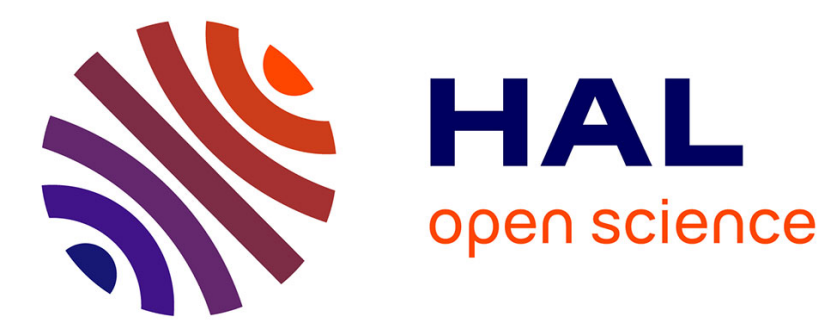

\title{
Do alternative reproductive tactics predict problem-solving performance in African striped mice?
}

Céline Rochais, Neville Pillay, Carsten Schradin

\section{To cite this version:}

Céline Rochais, Neville Pillay, Carsten Schradin. Do alternative reproductive tactics predict problemsolving performance in African striped mice?. Animal Cognition, 2021, 10.1007/s10071-020-01459-z . hal-03131294

\author{
HAL Id: hal-03131294 \\ https://hal.science/hal-03131294
}

Submitted on 4 Feb 2021

HAL is a multi-disciplinary open access archive for the deposit and dissemination of scientific research documents, whether they are published or not. The documents may come from teaching and research institutions in France or abroad, or from public or private research centers.
L'archive ouverte pluridisciplinaire HAL, est destinée au dépôt et à la diffusion de documents scientifiques de niveau recherche, publiés ou non, émanant des établissements d'enseignement et de recherche français ou étrangers, des laboratoires publics ou privés. 


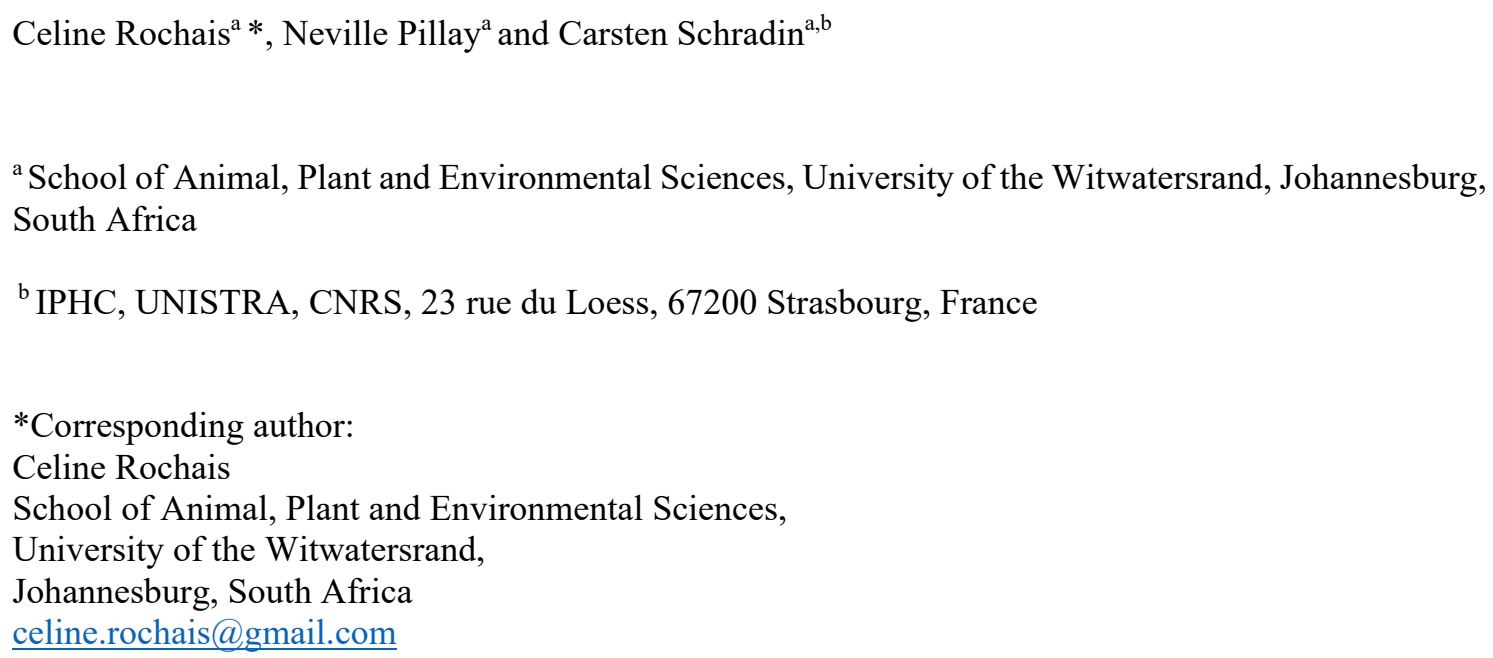

\section{Published as}

Rochais, C., Pillay, N. \& Schradin, C. 2021. Do alternative reproductive tactics predict problem-solving performance in African striped mice? Animal Cognition. https://doi.org/10.1007/s10071-020-01459-z

https://rdcu.be/cdkjy

\section{Abstract}

In changing environments, animals face unexpected problems to solve. Not all individuals in a population are equally able to solve new problems. It still remains unclear what factors (e.g., age, body condition) influence the propensity of problem-solving. We investigated variation in problem-solving performance among males following alternative reproductive tactics (ARTs). We studied a free-ranging population of the African striped mouse (Rhabdomys pumilio). Adult male striped mice can employ 3 ARTs: 1) dominant group-living breeders, 2) philopatrics living in their natal group, and 3) solitaryliving roamers. ARTs in male striped mice reflect differences in competitiveness, sociality and physiology which could influence their problem-solving performance. We tested a total of 48 males in two years with two tasks: a string-pulling task to reach food and a door opening task to reach the nest. Since male striped mice differ in personality traits independent of ARTs, we also measured activity, boldness and exploration. In addition, we assessed the association of body condition and age with problem-solving. Problem-solving was related the interaction of age and ARTs. The younger philopatrics had better performance in a food extraction task whereas the older breeders were faster at solving the door opening task. Individual differences in traits related to personality were significant correlates of problem-solving performance: pro-active mice (i.e., more active and explorative and bolder) performed better in both tasks. Finally, problem-solving performance was not consistent 
between the two tasks. Our study provides evidence of correlates of ARTs, age and personality on problem-solving abilities.

Key words: Alternative Reproductive Tactics, cognition, consistency, innovation, personality

\section{Introduction}

In changing environments, animals face unexpected problems to solve, such as foraging for particular foods or predator avoidance (Sol et al. 2005; Ramsey et al. 2007). One way to respond to such challenges is innovation, defined as developing solutions to a novel problem, or novel solutions to an existing problems; thus, problem-solving ability is often used as proxy for innovation (Lefevre et al. 1997; Laland and Reader 1999; Ramsey et al. 2007). One approach to studying innovation is to present novel problem-solving tasks to individuals in captivity (e.g., in birds: Heinrich and Bugnyar 2005; Boogert et al. 2008, in primates: Manrique et al. 2013), to free-living animals temporarily held in captivity (Ducatez et al. 2014) or to free-living animals directly in the field (Thornton and Samson 2012; Cauchard et al. 2013).

Not all individuals show a similar ability to solve problems, resulting in variation within species (Reader and Laland 2003). For example, in a free-living population of great tits (Parus major), individual variation in lever and string-pulling problem-solving tasks were explained by the age and the natal origin (Cole et al. 2011). The reasons for individual differences in problem-solving are not well understood. Two hypotheses have been proposed to explain individual variation in problem-solving abilities (reviewed in Amici et al. 2019). The 'Excess of Energy' (EE) hypothesis maintains that problem-solving is commonly displayed by animals with higher daily food intake and/or feeding efficiency, because these animals have more energy and/or time to devote to problem-solving, as compared to conspecifics in poorer physical condition (Kummer and Goodall 1985). The 'Bad Competitor' (BC) hypothesis claims that there is risks involved in problem-solving behaviour, such as decreased attention to predators (Laland and Reader 1999; Reader and Laland 2003). Both hypotheses suggest that members of different social status should vary in their ability to solve problems.

Problem-solving performance can be affected by social parameters such as dominance rank, group size, and reproductive tactic. In support of the EE hypothesis, dominance rank can be positively related to problem-solving (Zinner \& Wheeler 2012). Conversely, in support of the BC hypothesis, low ranking animals should solve novel problems because of a 'necessity drive innovation' due to reduced access to resources (Reader and Laland 2003; Thornton and Samson 2012). Studies report positive effects of group size on problem-solving abilities due to social facilitation/learning, whereas others report negative effects (Overington et al. 2009; Griffin et al. 2013) or no effect (Thornton and Samson 2012).

In species where individuals show alternative reproductive tactics (ARTs), it is possible that the ability to solve a new problem varies according to tactics. ARTs represent discrete reproductive phenotypes shown by different members of the same sex and population (Gross 1996). For example, in 
species with conditional ARTs, competitive and dominant males follow the 'bourgeois tactic' with the highest reproductive success whereas smaller, less competitive males follow the best of a bad job tactic' with lower reproductive success that nevertheless adds to their lifetime fitness (Dawkins 1980). Further, males following ARTs often differ in sociality, some being group- and others solitary-living (e.g., in the great gerbil, Rhombomys opimus; Randall et al. 2005). In species with conditional strategies, individuals can switch their tactic within their lifetime. For example, in striped mice (Rhabdomys pumilio), when males reach adulthood, some remain philopatric in their natal group and attempt to obtain copulations with neighbouring females. In the subsequent breeding season, philopatrics can become roamers first before becoming breeders. If philopatrics gain sufficient body mass, they can directly become breeders in a neighbouring group. Thus, in species where ARTs differ in competitive ability, difference in cognitive abilities between ARTs might also occur.

Variability among ARTs in solving a novel problem could be due to different proximate factors. For example, hormonal level differences among ARTs, which were found in male striped mice (Schradin and Yuen 2011), could influence cognitive processes such as problem-solving (Bókony et al. 2014). Males adopting different ARTs differ in their energy availability (Rimbach et al. 2019) and hence might have to trade-off energy investment between competing processes such as cognition and reproduction (Mery and Kawecki 2003). Social dominance rank and competitive ability, which differ between ARTs, can also influence problem-solving performance (e.g., Cole and Quinn 2012). Behavioural differences between ARTs (Rimbach et al. 2016) can also influence problem-solving. For example, time budgets could differ between roamers and breeders, and since roamers have larger home ranges, they might be more likely to encounter novel problems to solve compared to breeders (e.g., in Cape ground squirrels, Xerus inauris, Scantlebury et al. 2008).

Ultimately, cognitive ability may potentially undergo sexual selection (Boogert et al. 2011). Some studies have indicated that male problem-solving abilities enhance mate attraction (e.g., in satin bowerbird, Keagy et al. 2009), suggesting an association between cognition and reproductive success. Thus, breeder males showing better reproductive success (e.g., in African striped mice, Schradin and Lindholm 2011) may have enhanced cognititive processes (Smith et al. 2015). To date, the relationship between ARTs and problem-solving behaviours is poorly understood. Only one study investigated the relationship between cognitive traits and ARTs. In captive rose bitterling fish (Rhodeus ocellatus), spatial learning performance in a maze correlated positively with reproductive success of sneaker males, but not for the dominant guarding males (Smith et al. 2015).

Individual differences in problem-solving abilities have also been explained by other intrinsic characteristics. Personality traits, i.e., a set of individual differences in behaviour that are consistent across time and contexts (Réale et al. 2007), are known to be linked to problem-solving ability (Reader and Laland 2003; Auersperg et al. 2011). Boldness i.e., an individual's reactions to any risky situation (Réale et al. 2007), exploration i.e., an individual's reaction to any new situation - neophobia/neophilia are considered as part of exploration (Réale et al. 2007), and persistence i.e., number of attempts or the 
time that an animal spends interacting with the task (Griffin and Guez 2014) have been positively related to problem-solving performance (Reader and Laland 2003; Auersperg et al. 2011; Benson-Amram et al. 2013). Overall, it has been shown that more active, bolder, more exploratory (i.e., pro-active) individuals are expected to be faster at learning novel activity-based tasks (i.e., speed - accuracy trade off). In contrast, less active, less bold, slow exploring (i.e., reactive) animals that are more sensitive to environmental stimuli are suggested to be slower in learning new activity-based tasks, but also make more accurate decisions and store more information for longer periods of time (Sih and Del Giudice 2012; Griffin et al. 2015). The relationship between personality traits and problem-solving suggests problem-solving consistency across context (e.g., in guinea pigs, Cavia aperea, Guenther and Brust 2017). However, some authors suggest that cognitive abilities, including problem-solving, are not fixed traits, having no consistency in time (Soha et al. 2019) and susceptible to social and/or environmental changes (Aplin et al. 2015; Quinn et al. 2016).

Individual differences in age and body condition can influence problem-solving abilities. Juveniles are expected to solve novel problems more frequently than adults because they show a greater propensity to explore new objects (Morand-Ferron et al. 2011; Thornton and Samson 2012; BensonAmram et al. 2013). Some studies showed an effect of body condition on problem solving, with animals in poorer condition being more prone to solve novel problems (e.g., food-deprived and smallest: Laland and Reader 1999; Sol et al. 2005) but most studies failed to find a positive/negative correlation between body condition and problem-solving (Morand-Ferron et al. 2011; Thornton and Samson 2012; BensonAmram et al. 2013).

Here, we used a novel problem approach to investigate individual variation in innovative problem-solving among males following ARTs in a free-ranging population of the African striped mouse. The striped mouse is an ideal model to study the influence of ARTs on problem-solving abilities in the field. Philopatrics are the smallest and least competitive and breeding males the largest and most competitive males (Schradin et al. 2009a). Solitary living roamers have larger home ranges and experience territorial aggression by larger territorial breeding males (Schradin et al. 2012). Fitness (measured as male paternity) varies according to ARTs, being highest in territorial breeding males and lowest in philopatrics (Schradin and Lindholm 2011). Roamers were found to have higher basal blood glucose levels than breeders and philopatrics (Schradin et al. 2015). Following a recent study, in which we found that high blood glucose levels were related to lower cognitive performance in our striped mice population (Rochais et al. 2019), we would expect variation in cognition related to ARTs. Males with different ARTs differ in steroid hormone levels (Schradin et al. 2009a, 2013), which was shown to influence cognitive performance in other species e.g., house sparrows (Passer domesticus), in which individuals with lower levels of corticosterone solved a novel problem-solving task faster (Bókony et al. 2014). Personality differences has been shown in striped mice but did not differ between males ARTs and did not change when males switched tactic (Yuen et al. 2015). Therefore, different ARTs in male 
striped mice reflect differences in competitiveness, sociality, morphology and physiology which could influence their problem-solving behaviour.

Thus, our aim was to explore problem-solving differences according to ARTs and how they covary with intrinsic characteristics such as age, body condition and personality. We made 3 nonmutually exclusive predictions: 1) Problem-solving differences between ARTs will support the 'necessity drive innovation hypothesis' with smaller, younger and subordinate philopatrics showing better problem-solving performance because of their lower competitiveness and no alternative strategy; 2) More active, bolder and more explorative (i.e., proactive) individuals, regardless of ARTs, will show better problem-solving performance because they will be more prone to engage in a novel task; 3 ) Individual problem-solving performance will be consistent across contexts (i.e., different tasks), but a lack of an effect would suggest flexibility in the propensity to solve novel problems depending on the environmental conditions.

\section{Materials and Methods}

\section{Ethical note}

Animal ethical clearance was provided by the University of the Witwatersrand, Johannesburg, South Africa (No. 2018/09/46B). All procedures were in accordance with the ethical standards of the institution or practice at which the studies were conducted. We took care in ensuring the animals' welfare throughout the experimental procedure and afterwards. Striped mice were trapped using baited metal live traps placed directly at their nests in the shade under bushes. Traps were checked every 30 minutes. Trapped mice were marked using ear tags and equipped with radio transceivers. We usually trapped the mice again on the same day to check their health (e.g. checked ears, neck, eyes, ensuring no external airway obstruction due to radio transceivers). During cognitive tests, mice were transported in their traps and we checked their behaviour continuously via video recordings. No injury or death occurred due to the trapping and problem-solving tests. Mice were fed 5 pieces of bait after the problemsolving test to compensate for missed foraging opportunities.

\section{Study species}

Striped mice are diurnal and inhabit an open habitat allowing for direct behavioural observations in the field (Schradin and Pillay 2004). We studied a free-living population of African striped mice, consisting of several distinct social groups. Groups consisted of one breeding male, one to four breeding females and their offspring of both sexes that remained in their natal group after reaching adulthood (Schradin and Pillay 2004). Groups contained from 2 to 14 (mean \pm SE: $6.59 \pm 0.71$ ) adult individuals of both sexes during the study period. Striped mice typically breed in the austral winter / spring (August - November / December), corresponding to the period of highest rainfall (Schradin and Pillay 2005a). In captivity, striped mice can reach sexual maturity at around 6 weeks of age, but in free-living 
population, they typically do not reproduce in the breeding season in which they were born (Schradin and Pillay 2004).

\section{Study area and period}

The study was conducted at the Succulent Karoo Research Station in Goegap Nature Reserve, near Springbok in the Northern Cape Province, South Africa (S 29 $42.414^{\prime}$, E $18^{\circ} 02.526^{\prime}$ ). The area is arid, with an average annual rainfall of $160 \mathrm{~mm}$ (Rosh 2001). The vegetation is classified as Succulent Karoo. Up to twelve social groups of striped mice occupied our 10ha study area. The study took place during two breeding seasons from $31^{\text {st }}$ July to $19^{\text {th }}$ October $2018\left(1^{\text {st }}\right.$ year $)$ and from $1^{\text {st }}$ August to $3^{\text {rd }}$ September $2019\left(2^{\text {nd }}\right.$ year $)$. We measured the daily temperature $\left(1^{\text {st }}\right.$ year: $17.85 \pm 0.37{ }^{\circ} C ; 2^{\text {nd }}$ year: $\left.19.33 \pm 0.32^{\circ} \mathrm{C}\right)$ and daily rainfall $\left(1^{\text {st }}\right.$ year: $105.30 \mathrm{~mm} ; 2^{\text {nd }}$ year: $\left.48.90 \mathrm{~mm}\right)$ and food availability twice a month $\left(1^{\text {st }}\right.$ year: $4.09 \pm 0.39$ food plants/plot; $2^{\text {nd }}$ year: $2.54 \pm 0.21$ food plants/plot $)$. Since striped mice mainly feed on plants, we assessed their food availability through plant surveys. We used the Braun-Blanquet method (Wikum and Shanholtzer 1978) to conduct plant surveys on the $1^{\text {st }}$ and on the $15^{\text {th }}$ of each month at our field site. We recorded the number of food plant species for striped mice in eight monitoring plots of $4 \mathrm{~m}^{2}$ each (Schradin and Pillay 2005a).

\section{Study animals}

In the $1^{\text {st }}$ year, we studied 21 adult males, 5 breeders, 6 philopatrics from 12 different groups and 10 roamers. In the $2^{\text {nd }}$ year, we studied 27 males, 12 breeders, 2 philopatrics from 12 different groups and 13 roamers. Individuals were tested in only one year and never in both years of the study to avoid any learning effects acquired in year one influencing problem-solving in the next year, and also because most of mice died within one year; striped mice rarely live beyond a year.

\section{Trapping and marking}

The study population has been continuously monitored since 2002 by a combination of trapping, behavioural observations and radiotracking (Schradin and Pillay 2004). Each group is trapped (minimum of 6 trap days per month) and observed (minimum of 2 days per month) at its nesting site at least once per month. Striped mice were trapped using baited metal (Sherman-like) live traps (26 X 9 $X 9 \mathrm{~cm}$ ) placed directly at their nests in the shade under bushes where striped mice were nesting the night before. Bait was a small piece of a mix of bran flakes, sunflower oil and dried currants. Trapping sessions were conducted each morning ( 5 days a week) within the first hour after sunrise at different groups. Traps were checked 30 and 60 min after they were set. One evening trapping session was conducted each dusk (5 days a week) within 30 minutes after sunset (Schradin and Pillay 2004). Individuals were permanently marked using numbered metal ear tags (National Band and Tag Co., 
231 Newport, KY, USA). Additionally, each individual above $25 \mathrm{~g}$ was marked on the pelage with

232 commercial hair dye (Rapido, Pinetown, South Africa) to facilitate individual recognition during

233 behavioural observations (Schradin 2006). During trapping, mice were sexed and body mass ( $\pm 1 \mathrm{~g})$ and

234 length ( $\pm 1 \mathrm{~mm}$, from tip of the nose to the anus) were measured. All breeders and roamers and 7 of the

2358 philopatrics were fitted with a collar-mounted radiotransmitter (models BD-2C and PD-2C, Holohil,

236 Ontario, Canada) (Schradin and Pillay 2005a, b). Striped mice were radio-tracked at dusk (5 days a

237 week) to determine their nesting sites and whether individuals slept in groups or alone (Schradin and 238 Pillay 2005b).

239 The animals selected for study were born during the previous breeding season (i.e. 2017 for

240 those tested in year 1; 2018 for those tested in year 2). The age of mice was determined by using a

241 species-specific growth curve based on long-term continuous trapping data (Schradin et al. 2009b).

242 Upon first capture after birth, body mass (less than 30g) and the date of first capture were used to

243 estimate an individual's birth date using the species-specific growth curve. For mice with body mass of

244 more than $30 \mathrm{~g}$, age could not be determined reliably if it had not been marked previously. Of all mice

245 tested $(\mathrm{N}=48)$, age data were not available for $44 \%$ of the mice, many $(\mathrm{N}=15)$ of which were

246 immigrants to our study area.

247

\section{Determination of reproductive tactics}

Our long-term, constant monitoring of striped mouse groups and the environmental conditions in our study site, enabled us to track the tactic followed by each individual at all times. We defined philopatrics as adult males that stayed with their natal group (i.e., the group where they were previously trapped as juveniles). Breeding males were large adult males that had immigrated into a group that was not their natal group. Roamers were males that were sleeping alone for more than $70 \%$ of the time, spending the remaining time with different female partners, and which were not part of a social group (Schradin et al. 2009a, 2012).

\section{Personality and cognition tests}

Each morning, 2-4 striped mice were trapped (2 rounds of trapping spaced 30 min apart) at their nest within the first hour after sunrise and brought to a field laboratory (3.70 X $3.10 \times 2.40 \mathrm{~m})$ located within a 5-minute walking distance from the field site. The laboratory was split into two areas with a black opaque curtain hanging from the ceiling, one area used for testing the mice $(1.60 \times 3.10 \times 2.40$ $\mathrm{m}$ ) and the other area served as a hide for the experimenter. Before being tested, mice were placed in a separate quiet room next to the field laboratory and housed individually in plastic cages ( $22 \mathrm{X} 16.5 \mathrm{X}$ $14 \mathrm{~cm}$ ) with sand for bedding and an egg box as shelter. Mice were kept between 10 minutes and 80 minutes in the separate room but there was no influence of holding time on mice behaviour (supplementary material, Table $1 \& 2$ ). Mice were then taken individually to the laboratory for a 
personality test and then a food-extraction problem-solving test. Each test was performed in the same neutral arena made of white wood $(80 \times 65 \times 94 \mathrm{~cm})$. The arena was cleaned with $70 \%$ alcohol after each test.

\section{Personality test}

We measured personality traits (activity, boldness and exploration) that were previously shown to be consistent across time and tested repeatedly in another study of our study population (Yuen et al. 2015). We used the same protocol as Yuen et al (2015) study but to reduce the number of tests and handling stress, mice were only tested for personality traits once. Activity and boldness were measured using an open field test, lasting 5 minutes. Mice were placed in one corner of the arena and left for 5min and videotaped using a Microsoft HD web camera mounted over the centre of the arena and connected to a laptop. Activity was then recorded every 10 seconds using instantaneous scan sampling (1/0 sampling; Martin and Bateson 1993). Boldness was measured using continuous focal sampling (Martin and Bateson 1993) as the total time (in seconds) an individual spent in the open part of the arena (i.e., open field), defined as at least half-a-mouse length away from the wall of the arena (Yuen et al. 2015). Exploration was used as a third personality measurement, scored as the latency (in seconds) to first touch the problem-solving device during a shaping training phase of a food extraction task (see below), when the device used in task served as a novel object. Our method differed from that of the Yuen et al. (2015) study, since we used only a fixed object and they used both a fixed and a mobile object in the arena, and they found no behavioural differences in the response to these two novel objects (Yuen et al. 2015).

\section{Problem-solving task 1: food extraction in the field laboratory}

A food extraction problem-solving device was placed into the arena (electronic supplementary material 1). The device consisted of a grey PVC foraging grid $(20 \times 8 \times 3.5 \mathrm{~cm})$ containing 4 wells (each with $3.5 \mathrm{~cm}$ diameter and $2.5 \mathrm{~cm}$ depth) that were covered with grey PVC lids. A short cotton string $(3 \mathrm{~cm})$ was attached to each lid, which the mice could pull to open the lid. Each well contained a small piece of bran flake and a sunflower seed (highly preferred by striped mice).

The lid opening device was placed alongside a wall opposite to the test mouse (striped mice tend to avoid being in the middle of the arena). Mice were first trained for 5 minutes to search the wells using a shaping training where they could gain access to a food reward (bran flake and sunflower seed) by first being exposed to the lids only partially covering the wells. These 5 minutes allowed mice to habituate to the device and learn about the food inside the wells. We considered that a mouse explored a well when it placed its nose inside the hole. After 5 minutes of shaping training, we refilled the wells if they were emptied, all the lids of the wells were closed and the mouse was tested for $30 \mathrm{~min}$. In order to provide the mice with sufficient time to perform the task in an unfamiliar field laboratory environment, mice were tested on 2 consecutive days with the same food extraction procedure (i.e., 5 
min shaping training with lids partially opened and $30 \mathrm{~min}$ of testing resulting in $1 \mathrm{~h}$ of total testing per individual over 2 days). After day 1 of testing, mice were given 5 pieces of bait and released at their nest within a maximum of 2 hours after being trapped there. On day 2, mice were trapped again following the same procedure as day 1 . We tested mice on consecutive days since a longer period between tests could have increased the chances of mice disappearing from our field site due to predation or dispersal.

Problem-solving performance was later analysed from video footage. We recorded whether a mouse opened at least one lid (general success: yes/no), the total number of lids opened ( $0-4$ lids) and the latency of opening the $1^{\text {st }}, 2^{\text {nd }}, 3^{\text {rd }}$ and $4^{\text {th }}$ lid. We measured solving times, defined as how long it took an individual to open a lid for the $1^{\text {st }}, 2^{\text {nd }}, 3^{\text {rd }}$ and $4^{\text {th }}$ successful attempts, indicating a subject's efficiency in repeatedly opening the lids (Huebner et al. 2018). Solving time was measured from the time the mouse touched the lid/string with its mouth and/or front legs to the time the lid was opened. Using continuous focal sampling, we assessed individual persistence, defined as the time that an animal spent interacting with the task (Griffin and Guez 2014) by recording the total duration mice spent in contact with the device (i.e. sniffing, climbing, scratching) as a percentage of the total testing time. Persistence is associated with exploration propensity since more exploratory individuals would show short latency to touch the novel device. The mice which successfully opened one lid were characterized as 'solvers' whereas the ones which failed were characterized as 'non-solvers'. The total number of lids opened (04 lids) indicated the levels of performance or achievement in the task.

\section{Problem solving task 2: door opening test in the field}

Between 3 and 10 days after the food extraction task, the striped mice were subjected to a door opening task at their nests in the field. We used 41 of the 48 mice in the door opening task since 7 mice were not re-trapped within 6 days. After being trapped directly at their nests twice a day, mice were placed in a black testing box $(40 \times 30 \times 35 \mathrm{~cm})$ equipped with 2 black doors, both functional, situated $17 \mathrm{~cm}$ apart on the same side of the box (electronic supplementary material 2). The door system was designed to allow a mouse to escape and return to its nest (i.e., the reward stimulus) by pushing the door with its head and/or legs. The doors were hinged, so that even a light mouse could easily open it. Doors were shorter than the bottom of the box wall, allowing for a strip of external light entering the box and indicating their position. The subject was videotaped using a GoPro camera (AEE LYFE, S91B) mounted on the top of the box.

We conducted a pilot study ( $\mathrm{N}=8$ mice from outside of the field site) to assess how the mice responded to the experimental device. When we introduced the mice into the box for 15 minutes, some mice did not try to open the door and instead froze in the corner for an average of 5 minutes. Thus, in the present study, when a mouse did not attempt to open the doors after a maximum of 5 minutes, the experimenter opened both doors and mouse could go back to its nest. This was the case for some individuals during their first trial but all mice in our study eventually opened the door and where 
considered 'door-solvers'. Mice were tested repeatedly until they opened the door on three successive attempts, which all accomplished in a maximum of 6 trials (range: 3 to 6 trials; mean $\pm \mathrm{SE}=3.17 \pm$ 0.08). We measured the latency of the three successive successful trials (latency 1,2 and 3) and the number of trials taken to open the door until reaching three successive successes (from 3 to 6 ) as a measure of problem-solving performance.

\section{Statistical analyses}

The video-recordings of the personality and problem-solving tests were scored using the software Kinovea (Kinovea 0.8.15). Scoring was done by the same observer (C.R.) and by two field assistants who were naïve to the experimental treatment. We found high inter-observer reliability of (Personality: $0.86<$ rs $<0.98$; Food extraction task: $0.85<$ rs $<0.99$; Door opening task: $0.91<$ rs $<0.99$, Spearman rank order correlation).

All statistics were performed with R v. 3.6.1 (The R foundation for statistical computing, http://www.r-project.org/, Team 2019). The significance level was set at 0.05. Descriptive statistics are reported as means and standard errors. Independence and homogeneity of variances of the models were assessed by inspection of fitted values residuals using the plotresid function in RVAideMemoire package (Hervé, 2019). Models were constructed using the linear models (LM using a Gaussian distribution for continuous data: i.e., task 1: latency of $1^{\text {st }}, 2^{\text {nd }}, 3^{\text {rd }}, 4^{\text {th }}$ success, solving times and persistence; task 2 : latency of success in the $1^{\text {st }}, 2^{\text {nd }}$ and $3^{\text {rd }}$ trials) or general linear models (GLM using a Binomial distribution for yes/no data i.e., general success, or a Poisson distribution for given number of events: i.e., task 1: total number of successes; task 2: number of trials needed to reach 3 consecutive successful door openings), with $1 \mathrm{~m}$ and glm functions in Ime4 package (Bates et al. 2015). Statistical tests (Likelihood Ratio Test) were performed using the Anova function in car package with loglink function for Gaussian and Poisson distribution and logitlink function for Binomial distribution (Fox and Weisberg 2019). Post hoc tests were performed using the emmeans function in the emmeans package (Lenth, 2019), with a Tukey correction. We centred and scaled all continuous explanatory variables before running all models.

The effect of ARTs (i.e., breeders vs philopatrics vs roamers) on intrinsic characteristics was analysed using a linear model for each characteristic separately i.e., age and body condition (ratio body mass / length) as the dependent variables, ARTs and year of testing as fixed effects. Difference in personality according to ARTs was analysed by using a linear model with activity, boldness and exploration as the dependent variables, ARTs and year of testing as fixed effect. The relationship between different personality traits was analysed using two-tailed Spearman correlation since data were not normally distributed.

To analyse the potential effects of individual characteristics, such as age, body condition and ARTs, on performance in the problem-solving tasks, we fitted multiple models with the measures of test 
performance as response variables and age, body condition (covariates) and ARTs and year (categorical) as predictor variables. We used the ratio body mass / length as an indicator of body condition. We selected the model that best fitted our data by selecting the model that yielded the lowest Akaike's information criterion (AIC) (Dingemanse and Dochtermann 2013).

The influence of personality traits (i.e., activity + boldness + exploration) on problem-solving performances in both problem-solving tasks was analysed with a linear model with all continuous measurements and generalized linear model following a binomial distribution for yes/no data i.e., general success; or a Poisson distribution for a given number of events (i.e., task 1: total number of successes; task 2: number of trials needed to reach 3 consecutive successful door openings). We tested each personality trait instead of collapsing them into a single composite trait, to test which trait correlated best with problem-solving (Wat et al. 2020).

We tested for among-individual differences in problem-solving with multivariate models using the MCMCglmm package (Hadfield 2010) following Houslay and Wilson (2017). We assessed the amongindividual correlations $\left(\mathrm{r}_{\text {ind }}\right)$ and the within-individual correlations $\left(\mathrm{r}_{\mathrm{e}}\right)$ between the behaviour of striped mice in the problem-solving task 1 (i.e., lid opening solver versus non-solver; mean solving time for the $1^{\text {st }}, 2^{\text {nd }}, 3^{\text {rd }}$ and $4^{\text {th }}$ success) with their behaviour in task 2 (i.e., number of trials to succeed in 3 successive attempts, mean latency to open the door in the $1^{\text {st }}, 2^{\text {nd }}, 3^{\text {rd }}$ trials). A $4 \times 4$ correlation matrix was fitted for the among individual level (ID) to estimate among-individual variance $V_{\text {ind }}$ and correlation $\mathrm{r}_{\text {ind }}$ between traits. A $4 \times 4$ correlation matrix was also fitted at the residual level to estimate residual variance $V_{e}$ and correlation $r_{e}$ between traits. The $95 \%$ confidence intervals for $r_{i n d}$ and $r_{e}$ were calculated using profile likelihoods with the proLik function in nadiv (Wolak 2012).

\section{Results}

\section{Intrinsic characteristics and ARTs}

Philopatrics were younger ( $3.40 \pm 0.82$ months $)$ compared to breeders $(11.87 \pm 0.88$ months $)$ and roamers ( $8.14 \pm 0.48$ months) (LM: $\mathrm{N}=48, \chi^{2}{ }_{1}=25.45, \mathrm{P}<0.001$, supplementary material, Table 3$)$. Philopatrics were lighter $(42.93 \pm 3.41 \mathrm{~g})$ compared to breeders $(54.30 \pm 1.93 \mathrm{~g})$ but not roamers (48.62 \pm 1.71 g) (LM: $\mathrm{N}=48, \chi^{2}{ }_{1}=11.42, \mathrm{P}=0.003$, supplementary material, Table 3$)$. Philopatrics were also smaller $(111.14 \pm 2.37 \mathrm{~mm})$ compared to breeders $(119.93 \pm 1.83 \mathrm{~mm})$ but not roamers $(116.19 \pm 2.02$ $\mathrm{mm}$ ) (LM: $\mathrm{N}=48, \chi^{2}{ }_{1}=3.67, \mathrm{P}=0.034$, supplementary material, Table 3 ). Further, philopatrics' body condition $(0.37 \pm 0.03)$ differed from breeders $(0.45 \pm 0.01)$ but not roamers $(0.42 \pm 0.01)(\mathrm{LM}: \mathrm{N}=$ $48, \chi_{1}^{2}=7.57, \mathrm{P}=0.016$, supplementary material, Table 3 ).

In the study subjects, activity, boldness and exploration were positively correlated (Spearman rank correlation: activity / boldness, $\mathrm{N}=48, \mathrm{r}=0.276, \mathrm{P}=0.050$, activity / exploration: $\mathrm{r}=-0.414, \mathrm{P}=0.004$, boldness / exploration: $\mathrm{r}=-0.356, \mathrm{P}=0.016$ ) (Fig $1 \mathrm{a}, \mathrm{b}, \mathrm{c}$ ). Activity and boldness did not differ according to ARTs (LM: $\mathrm{N}=48, \chi_{2}^{2}=5.49, \mathrm{P}=0.075 ; \chi^{2}{ }_{2}=1.15, \mathrm{P}=0.548$, respectively). Exploration 
differed according to ARTs: philopatrics took longer to touch the novel device $(173.52 \pm 54.39 \mathrm{~s})$ than breeders $(38.23 \pm 12.81 \mathrm{~s})$ but not roamers $(99.57 \pm 21.14 \mathrm{~s})\left(\mathrm{LM}: \mathrm{N}=48, \chi^{2}{ }_{1}=5.98, \mathrm{P}=0.0053\right.$; $\mathrm{t}$ test: breeders $v s$ philopatrics: $\mathrm{t}_{42}=-3.17, \mathrm{P}=0.0080$; breeders $v s$ roamers: $\mathrm{t}_{42}=-1.64, \mathrm{P}=0.238$, philopatrics vs roamers: $\mathrm{t}_{42}=2.08, \mathrm{P}=0.105$ ).

\section{Problem solving task 1: food extraction in the field laboratory}

Of all 48 mice tested, 27 (57\%) were 'solvers' (i.e., opened at least 1 lid) of which 5 (18\%) opened just one lid, 6 (22\%) opened 2 lids, 8 (29\%) opened 3 lids and 8 (29\%) opened all 4 lids. The range of latency to first touch the device varied between 0.5 and 361 seconds $(24.55 \pm 9.31 \mathrm{~s})$. Only 2 mice never touched the device. For solvers, the latency to open the $1^{\text {st }}$ lid was $16.99 \pm 2.04$ min (range: 0.24 to 49.37 minutes), $22.71 \pm 2.16 \mathrm{~min}$ (range: 3.08 to 60.90 minutes) for the $2^{\text {nd }} l i d, 22.80 \pm 1.71 \mathrm{~min}$ (range: 5.07 to 41.80 minutes) for the $3^{\text {rd }}$ lid and $25.65 \pm 2.23 \mathrm{~min}$ (range 5.27 to 51.47 minutes) for the $4^{\text {th }}$ lid. The solving time, i.e., time needed for opening the $1^{\text {st }}$ lid was between 1.23 and 20.12 seconds $(6.00 \pm$ $0.59 \mathrm{~s}), 1.19$ and 6.97 seconds for the $2^{\text {nd }}$ lid $(3.41 \pm 0.23 \mathrm{~s}), 0.84$ and 15.24 seconds for the $3^{\text {rd }}$ lid ( 4.00 $\pm 0.50 \mathrm{~s})$, and between 1.09 and 15.67 seconds for the $4^{\text {th }}$ lid $(5.35 \pm 0.73 \mathrm{~s})$. The persistence time (i.e., the time that an animal spent interacting with the device) was between 0 ( 2 mice showed freezing behaviour and never interacted with the device) and $29 \%$ of the testing time $(9.62 \pm 1.00 \%)$.

There was no influence of intrinsic characteristics (ARTs, age, body condition) or year of testing on mice general success (yes/no) (Table 1). There was a significant interaction between ARTs and age on the total number of successes (number of lids opened 0-4) (GLM: $\mathrm{N}=48 ; \chi^{2}{ }_{2}=6.02, \mathrm{P}=0.049$ ). Philopatrics, which were younger, opened more lids compared to breeders which were older (GLM: N $=48 ; \chi^{2}{ }_{1}=10.33, \mathrm{P}=0.0003, \mathrm{t}$ test: $\mathrm{N}_{\text {breeders }}=17, \mathrm{~N}_{\text {philopatrics }}=8, \mathrm{t}_{20}=2.35, \mathrm{P}=0.04$ ) (Fig 2). There was no influence of intrinsic characteristics on latencies to open the $1^{\text {st }}, 2^{\text {nd }}, 3^{\text {rd }}$ and $4^{\text {th }}$ lids (Table 1 ). However, there was a significant influence of age on the first solving time: younger mice were quicker to open the $1^{\text {st }}$ lid (LM: $\left.\mathrm{N}=48 ; \chi^{2}{ }_{2}=8.15, \mathrm{P}=0.046\right)$ (Fig 3$)$. There was no impact of intrinsic characteristics on the persistence time (Table 1).

Personality traits influenced problem-solving performance (supplementary material, Table 4). Bolder mice showed higher total number of successes (opening 0-4 lids) (GLM: $\mathrm{N}=48 ; \chi^{2}{ }_{1}=4.38, \mathrm{P}=$ 0.039 ); activity and exploration did not affect the total number of successes (GLM: $\mathrm{N}=48 ; \chi^{2}{ }_{1}=0.26$, $\mathrm{P}=0.612 ; \chi_{1}^{2}=0.04, \mathrm{P}=0.849$, respectively) (supplementary material, Table 4 ). The more active mice showed shorter latency of $1^{\text {st }}$ success $\left(\mathrm{LM}: \mathrm{N}=48 ; \chi_{1}^{2}=4.48, \mathrm{P}=0.046\right)$; boldness and exploration did not affect latency to first success ( $\mathrm{LM}: \mathrm{N}=48 ; \chi^{2}{ }_{1}=0.72, \mathrm{P}=0.404 ; \chi^{2}{ }_{1}=3.67, \mathrm{P}=0.068$, respectively). The mice which were more persistent were also more active and explorative (LM: $\mathrm{N}=48 ; \chi^{2}{ }_{1}=6.37, \mathrm{P}$ $\left.=0.015 ; \chi^{2}{ }_{1}=8.39, \mathrm{P}=0.006\right)$. There was no effect of boldness on attempting to open lids (LM: $\mathrm{N}=$ $\left.48 ; \chi_{1}^{2}=2.39, \mathrm{P}=0.129\right)$. 
All mice tested were 'door-solvers'. The number of trials required to successfully open the door during 3 consecutive trials varied between 3 and 6 trials $(3.17 \pm 0.08)$. The latency to open the door decreased with the number of trials, suggesting that mice learnt the task quickly and improved their performance ( $\left.\mathrm{LM}, \mathrm{N}=41 ; \chi_{2}^{2}=60.01, \mathrm{p}<0.0001\right)$. The latency in the $1^{\text {st }}$ trial was between 1 and 201 seconds $(41.49 \pm 6.65 \mathrm{~s}), 1$ and 50 seconds in the $2^{\text {nd }}$ trial $(12.87 \pm 1.78 \mathrm{~s})$, and 1 and 123 seconds in the $3^{\text {rd }}$ trial $(12.15 \pm 2.91 \mathrm{~s})$.

There was no effect of intrinsic characteristics (ARTs, age, body condition) or year of testing on the number of trials to solve the problem-solving task (Table 2). There was a significant influence of age of mice on the latency to open the door for the $1^{\text {st }}$ and $2^{\text {nd }}$ trials: younger mice showed higher latency to open the door ( $\left.\mathrm{LM}, \mathrm{N}=41 ; \chi^{2}{ }_{1}=5.66, \mathrm{P}=0.035 ; \chi^{2}{ }_{1}=10.96, \mathrm{P}=0.006\right)$ (Fig 4). There was also a significant influence of ARTs on the latency to open the door for the $2^{\text {nd }}$ trial: philopatrics showed higher latency to open the door $\left(\mathrm{LM}, \mathrm{N}=41 ; \chi_{2}^{2}=5.14, \mathrm{P}=0.024\right.$; $\mathrm{t}$ test: breeders $v$ s philopatrics: $\mathrm{t}_{37}=$ $-2.63, \mathrm{P}=0.032$; breeders $v s$ roamers: $\mathrm{t}_{37}=-0.16, \mathrm{P}=0.987$, philopatrics $v s$ roamers: $\mathrm{t}_{37}=2.61, \mathrm{P}=$ $0.033)$ There was no influence of intrinsic characteristics on the latency to open the door in the $3^{\text {rd }}$ trial (Table 2).

The number of trials to solve the door opening problem-solving task did not differ according to personality traits (GLM: $\mathrm{N}=41, \chi_{1 \text { activity }}^{2}=0.02, \mathrm{P}=0.899 ; \chi_{1 \text { boldness }}^{2}=0.01, \mathrm{P}=0.955 ; \chi^{2}{ }_{1 \text { exploration }}=$ $1.18, \mathrm{P}=0.283$ ) (supplementary material, Table 5 ) but the more active and boldest mice showed shorter latency to open the door in the $1^{\text {st }}$ trial $\left(\mathrm{LM}, \mathrm{N}=41 ; \chi_{1 \text { activity }}^{2}=8.91, \mathrm{P}=0.005 ; \chi_{1 \text { boldness }}^{2}=5.49, \mathrm{P}=\right.$ $0.024 ; \chi_{1}^{2}$ exploration $\left.=0.45, \mathrm{P}=0.507\right)$. There was no influence of personality on the latency to open the door in the $2^{\text {nd }}$ and $3^{\text {rd }}$ trials (supplementary material, Table 5).

\section{Relationship between the two problem-solving tasks}

Performance during the food extraction task did not predict the door opening performance. None of the within and among individual correlations were significant (MCMCglmm, supplementary material, Table 6).

\section{Discussion}

Our study showed that intrinsic factors such as age and ARTs influenced individual problemsolving performance in a free-living rodent population. The younger philopatrics had better performance (greater number of success, faster solving times) in a food extraction task whereas the older breeders were faster at solving the door opening task. Individual differences in traits related to personality were significant correlates of problem-solving performance with pro-active mice (i.e., more active, explorative and bolder mice) performing better (greater number of success, faster latencies). 
492 Finally, problem-solving performance in a field laboratory did not predict performance in a door

493 opening task conducted in an arena directly in the field. Together, these results provide the first detailed

494 empirical study of the difference in problem-solving performance in striped mice and reveal the 495 contribution of intrinsic characteristics.

496 We found significant individual differences in the probability of solving a novel problem in a free497 living population of striped mice. These individual differences were not related to body condition (body 498 mass and length). However, we found an effect of age in interaction with ARTs, with the younger 499 philopatrics being more likely to solve the food extraction problem (better number of success, faster 500 solving times) than older breeders. Interestingly, the difference in problem-solving between younger 501 and older mice remained when controlling for the total duration of attempts (persistence). This suggests 502 that younger mice did not simply engage with the device for longer, but they had better technical or 503 cognitive abilities and were more efficient than the older males. Few studies have examined individual 504 differences in innovative problem-solving in the nature; some of these report no age effect (Keagy et 505 al. 2009), little age effect (Cole et al. 2011; Morand-Ferron et al. 2011) or increased success in older 506 adults (Gajdon et al. 2006). Our findings support the 'necessity drives innovation hypothesis', which 507 predicts increased problem-solving rates in poor competitors and therefore in younger individuals 508 (Reader and Laland 2003; Morand-Ferron et al. 2011; Cole and Quinn 2012).

509 Our study showed that older breeder mice were faster at solving the door opening problem. This 510 effect was unlikely to be due to a difference in physical strength, since the body condition of younger 511 mice did not influence door opening performance. One explanation could be that older mice were more 512 motivated to escape the box to return to their nest with unguarded females and pups compared to 513 philopatrics and roamers. Thus, the better performance of breeders in the escape box could be related 514 to their need to maintain their social status.

515 We found a significant interaction between age and ARTs in performances of both problem-solving 516 tasks. It is difficult to disentangle the influence of intrinsic variables since philopatrics are younger, 517 smaller and less competitive than breeding males which are older, the largest and most competitive 518 males (Schradin et al. 2009a). For this reason, we expected that the different ARTs (linked to other 519 intrinsic characteristics) in striped mice would predict problem-solving ability, related to, for example, 520 differences in energy availability (Rimbach et al. 2016). For instance, the 'Bad competitor' hypothesis 521 suggests that juveniles/subadults should show more foraging novel problem-solving because they have 522 higher metabolic costs (metabolic demands leading to stronger response to food deprivation) and thus 523 need to incur extra risks in order to survive (Griffin et al. 2014).

524 Our results do not strictly favour either the EE or BC hypothesis since younger philopatrics 525 performed better in the food extraction task and the older breeders in the door opening task. 526 Furthermore, the low between year problem-solving consistency among ARTs, suggests changes in 527 problem-solving within an individual's lifetime. This flexibility in ARTs is uncoupled from personality 528 (Yuen et al. 2015) and possibly also cognition, such a problem-solving. Problem-solving is not a fixed 
cognitive trait and can change via social learning (e.g., Aplin et al. 2015) or because of environmental changes (e.g., Prasher et al. 2019). Such potential intrinsic and extrinsic influences suggest changes in problem-solving within an individual's lifetime.

Individual differences in personality traits are important predictors of problem-solving performance in other species (reviewed in Amici et al. 2019). In our study, more active striped mice had shorter latencies of first success in the food extraction and the door opening tasks. Bolder striped mice opened more lids for food and showed shorter latencies to open the door during the third trial. More explorative mice spent more time attempting to open the lids which indicates persistence (Griffin and Guez 2014). Overall, pro-active (more active, explorative and bolder) mice showed better performance in both tasks. In striped mice, personality did not change when males switched tactic (Yuen et al. 2015), suggesting consistency across time and context, which could explain why it was also more consistent in predicting problem-solving performance. However, other studies show no link between problem-solving and personality traits (e.g., Griffin and Guez 2014). This suggests that further studies are needed about the phenotypic covariance of behaviour into between- and within-individual components, a prerequisite for demonstrating that between-individual variation in a personality trait is related to between-individual variation in cognition.

Some studies suggest between- and within-individual consistency in cognitive abilities across time and contexts (e.g., Morand-Ferron et al. 2011). Cross-contextual consistency will require demonstrating that an individual performs similarly in two similar but different tasks. In our study, problem-solving performance in a food extraction task conducted in a field laboratory did not correlate with the performance in an escape box door opening task conducted in an arena directly in the field. Similarly, studies of some bird species, found no consistency problem-solving in individuals tested in nature and in captivity (Webster and Lefebvre 2001; Morand-Ferron et al. 2011). This could be related to differential habituation responses to social isolation and/or novel arena in captivity. This also suggests that some individuals can be good performers in one or several specific tasks and poor performers in other tasks and results in weak cross-contextual consistency.

In conclusion, our study suggests that intrinsic factors such as age and personality which covary with ARTs are associated with inter-individual differences in problem-solving in striped mice. These differences were not directly associated with alternative reproductive tactics. Personality traits seemed to be important predictors of problem-solving performance. In future, both repeated problem-solving and personality tests are needed to confirm among and within individual consistency in cognition related to personality.

Acknowledgments: This study was made possible by the administrative and technical support of the Succulent Karoo Research Station (registered South African NPO 122-134). We thank Richard Askew, Florian Drouard, Margaux Duparcq, Arielle Farrell, Leon Kotze, Gildas Lemonnier, Pauline Vuarin, Richard Weil and Lindy Wolhuter for assistance in the field. We are grateful to Margaux Duparcq and 
Leon Kotze for the blind video analyses and to Hoël Hotte and Pierre Uhlrich for building the devices used in experiments. We extend our thanks to Alain Bellido for statistical assistance. We also thank three anonymous referees for comments that greatly improved the manuscript.

\section{Declaration}

Funding: This research was supported by a fellowship (to C.R.) by the University of the Witwatersrand and by the CNRS, France.

Conflict of Interest: The authors declare no conflict of interest.

Ethics approval: Animal ethical clearance was provided by the University of the Witwatersrand, Johannesburg, South Africa (No. 2018/09/46B).

Authors' contributions: All authors participated to the conception and the design of the experiments.

C.R. performed the experiments and analysed the data. All authors contributed to writing the paper.

\section{References}

Amici F, Widdig A, Lehmann J, Majolo B (2019) A meta-analysis of interindividual differences in innovation. Anim Behav 155:. https://doi.org/10.1016/j.anbehav.2019.07.008

Aplin LM, Farine DR, Morand-Ferron J, et al (2015) Experimentally induced innovations lead to persistent culture via conformity in wild birds. Nature 518:538-541. https://doi.org/10.1038/nature13998

Auersperg AMI, von Bayern AMP, Gajdon GK, et al (2011) Flexibility in Problem Solving and Tool Use of Kea and New Caledonian Crows in a Multi Access Box Paradigm. PLoS One 6:e20231. https://doi.org/10.1371/journal.pone.0020231

Bates D, Mächler M, Bolker BM, Walker SC (2015) Fitting linear mixed-effects models using lme4. J Stat Softw 67:. https://doi.org/10.18637/jss.v067.i01

Benson-Amram S, Weldele ML, Holekamp KE (2013) A comparison of innovative problem-solving abilities between wild and captive spotted hyaenas, Crocuta crocuta. Anim Behav 85:349-356. https://doi.org/10.1016/j.anbehav.2012.11.003

Bókony V, Lendvai ÁZ, Vágási CI, et al (2014) Necessity or capacity? Physiological state predicts problem-solving performance in house sparrows. Behav Ecol 25:124-135. https://doi.org/10.1093/beheco/art094

Boogert NJ, Fawcett TW, Lefebvre L (2011) Mate choice for cognitive traits: A review of the evidence in nonhuman vertebrates. Behav Ecol 22:447-459. https://doi.org/10.1093/beheco/arq173

Boogert NJ, Reader SM, Hoppitt W, Laland KN (2008) The origin and spread of innovations in starlings. Anim Behav 75:1509-1518. https://doi.org/10.1016/j.anbehav.2007.09.033 
Cauchard L, Boogert NJ, Lefebvre L, et al (2013) Problem-solving performance is correlated with reproductive success in a wild bird population. Anim Behav 85:19-26. https://doi.org/10.1016/j.anbehav.2012.10.005

Cole EF, Cram DL, Quinn JL (2011) Individual variation in spontaneous problem-solving performance among wild great tits. Anim Behav 81:491-498. https://doi.org/10.1016/j.anbehav.2010.11.025

Cole EF, Quinn JL (2012) Personality and problem-solving performance explain competitive ability in the wild. Proc R Soc B Biol Sci 279:1168-1175. https://doi.org/10.1098/rspb.2011.1539

Dawkins R (1980) Good strategy or evolutionary stable strategy? In: Sociobiology: Beyond Nature/ Nurture, eds Barlow. Westview, Boulder, CO., pp 331-367

Dingemanse NJ, Dochtermann NA (2013) Quantifying individual variation in behaviour: Mixedeffect modelling approaches. J Anim Ecol 82:39-54. https://doi.org/10.1111/1365-2656.12013

Ducatez S, Audet JN, Lefebvre L (2014) Problem-solving and learning in Carib grackles: individuals show a consistent speed-accuracy trade-off. Anim Cogn 18:485-496. https://doi.org/10.1007/s10071-014-0817-1

Fox J, Weisberg S (2019) An R Complanion to Applied Regression (3 ed.). Sage

Griffin AS, Diquelou M, Perea M (2014) Innovative problem solving in birds: A key role of motor diversity. Anim Behav 92:221-227. https://doi.org/10.1016/j.anbehav.2014.04.009

Griffin AS, Guez D (2014) Innovation and problem solving: A review of common mechanisms. Behav Processes 109:121-134. https://doi.org/10.1016/J.BEPROC.2014.08.027

Griffin AS, Guillette LM, Healy SD (2015) Cognition and personality: an analysis of an emerging field. Trends Ecol Evol 207-2014. https://doi.org/https://doi.org/10.1016/j.tree.2015.01.012

Griffin AS, Lermite F, Perea M, Guez D (2013) To innovate or not: Contrasting effects of social groupings on safe and risky foraging in Indian mynahs. Anim Behav 86:1291-1300. https://doi.org/10.1016/j.anbehav.2013.09.035

Gross MR (1996) Alternative reproductive strategies and tactics: Diversity within sexes. Trends Ecol. Evol. 11:92-98

Guenther A, Brust V (2017) Individual consistency in multiple cognitive performance: behavioural versus cognitive syndromes. Anim Behav. https://doi.org/10.1016/j.anbehav.2017.06.011

Guenther A, Brust V, Dersen M, Trillmich F (2014) Learning and personality types are related in cavies (cavia aperea). J Comp Psychol 128:74-81. https://doi.org/10.1037/a0033678

Hadfield JD (2010) MCMC methods for multi-response generalized linear mixed models: The MCMCglmm R package. J Stat Softw 33:1-22. https://doi.org/10.18637/jss.v033.i02

Heinrich B, Bugnyar T (2005) Testing Problem Solving in Ravens: String-Pulling to Reach Food. Ethology 111:962-976. https://doi.org/10.1111/j.1439-0310.2005.01133.x

Hervé M (2019) RVAideMemoire: Testing and Plotting Procedures for Biostatistics. R package version 0.9-73. 
Houslay TM, Wilson AJ (2017) Avoiding the misuse of BLUP in behavioural ecology. Behav Ecol 28:948-952. https://doi.org/10.1093/beheco/arx023

Huebner F, Fichtel C, Kappeler PM (2018) Linking cognition with fitness in a wild primate: Fitness correlates of problem-solving performance and spatial learning ability. Philos Trans R Soc B Biol Sci 373:. https://doi.org/10.1098/rstb.2017.0295

Keagy J, Savard J-F, Borgia G (2009) Male satin bowerbird problem-solving ability predicts mating success. Anim Behav 78:809-817. https://doi.org/10.1016/J.ANBEHAV.2009.07.011

Kummer H, Goodall J (1985) Conditions of Innovative Behaviour in Primates. Philos Trans R Soc B Biol Sci 308:203-214. https://doi.org/10.1098/rstb.1985.0020

Laland KN, Reader SM (1999) Foraging innovation in the guppy. Anim Behav 57:331-340. https://doi.org/10.1006/anbe.1998.0967

Lefevre L, Whittle P, Lascaris E, Finkelstein A (1997) Feeding innovations and forebrain size in birds. Anim Behav 53:549-560. https://doi.org/10.1006/anbe.1996.0330

Lenth R (2019) emmeans: Estimated Marginal Means, aka Least-Squares Means. https://cran.rproject.org/package $=$ emmeans

Manrique HM, Völter CJ, Call J (2013) Repeated innovation in great apes. Anim Behav 85:195-202. https://doi.org/10.1016/j.anbehav.2012.10.026

Martin P, Bateson P (1993) Measuring behaviour. Cambridge University Press, Cambridge

Massen JJM, Antonides A, Arnold AMK, et al (2013) A behavioral view on chimpanzee personality: Exploration tendency, persistence, boldness, and tool-orientation measured with group experiments. Am J Primatol 75:947-958. https://doi.org/10.1002/ajp.22159

Mery F, Kawecki TJ (2003) A fitness cost of learning ability in Drosophila melanogaster. Proc R Soc B Biol Sci 270:2465-2469. https://doi.org/10.1098/rspb.2003. 2548

Morand-Ferron J, Cole EF, Rawles JEC, Quinn JL (2011) Who are the innovators? A field experiment with 2 passerine species. Behav Ecol 22:1241-1248. https://doi.org/10.1093/beheco/arr120

Overington SE, Cauchard L, Morand-ferron J, Lefebvre L (2009) Innovation in groups : does the proximity of others facilitate or inhibit performance ? Behaviour 146:1543-1564

Prasher S, Evans JC, Thompson MJ, Morand-Ferron J (2019) Characterizing innovators: Ecological and individual predictors of problem-solving performance. PLoS One 14:. https://doi.org/10.1371/journal.pone.0217464

Quinn JL, Cole EF, Reed TE, Morand-Ferron J (2016) Environmental and genetic determinants of innovativeness in a natural population of birds. Philos Trans R Soc B Biol Sci 371: https://doi.org/10.1098/rstb.2015.0184

Ramsey G, Bastian ML, Van schaik C (2007) Animal innovation defined and operationalized. Behav Brain Sci 30:. https://doi.org/10.1017/S0140525X07002373

Randall JA, Rogovin K, Parker PG, Eimes JA (2005) Flexible social structure of a desert rodent, Rhombomys opimus: philopatry, kinship, and ecological constraints. Behav Ecol 16:961-973. 
https://doi.org/10.1093/beheco/ari078

Reader SM, Laland KN (2003) Animal Innovation. Oxford University Press, New York, NY

Réale D, Reader SM, Sol D, et al (2007) Integrating animal temperament within ecology and evolution. Biol Rev 82:291-318. https://doi.org/10.1111/j.1469-185X.2007.00010.x

Rimbach R, Blanc S, Zahariev A, et al (2019) Daily energy expenditure of males following alternative reproductive tactics: Solitary roamers spend more energy than group-living males. Physiol Behav 199:359-365. https://doi.org/10.1016/j.physbeh.2018.12.003

Rimbach R, Willigenburg R, Schoepf I, et al (2016) Young But Not Old Adult African Striped Mice Reduce Their Activity in the Dry Season When Food Availability is Low. Ethology 122:828840. https://doi.org/10.1111/eth.12527

Rochais C, Maille A, Jäger J, et al (2019) How does cognitive performance change in relation to seasonal and experimental changes in blood glucose levels? Anim Behav 158:149-159. https://doi.org/10.1016/j.anbehav.2019.10.011

Rosh H (2001) The identification and description of the management units of the Goegap Nature Reserve. Koedoe 44:17-30

Scantlebury M, Waterman JM, Bennett NC (2008) Alternative reproductive tactics in male Cape ground squirrels Xerus inauris. Physiol Behav 94:359-367. https://doi.org/10.1016/j.physbeh.2008.02.003

Schradin C (2006) Whole-day follows of striped mice [Rhabdomys pumilio], a diurnal murid rodent. J Ethol 24:37-43. https://doi.org/10.1007/s10164-005-0158-2

Schradin C, Kenkel W, Krackow S, Carter CS (2013) Staying put or leaving home: Endocrine, neuroendocrine and behavioral consequences in male African striped mice. Horm Behav 63:136-143. https://doi.org/10.1016/j.yhbeh.2012.10.004

Schradin C, Lindholm AK (2011) Relative fitness of alternative male reproductive tactics in a mammal varies between years. J Anim Ecol 80:908-917. https://doi.org/10.1111/j.13652656.2011.01831.x

Schradin C, Lindholm AK, Johannesen J, et al (2012) Social flexibility and social evolution in mammals: A case study of the African striped mouse (Rhabdomys pumilio). Mol Ecol 21:541553. https://doi.org/10.1111/j.1365-294X.2011.05256.x

Schradin C, Pillay N (2005a) Demography of the striped mouse (Rhabdomys pumilio) in the succulent karoo. Mamm Biol 70:84-92. https://doi.org/10.1039/DT9850000663

Schradin C, Pillay N (2004) The Striped Mouse (Rhabdomys pumilio) From the Succulent Karoo, South Africa: A Territorial Group-Living Solitary Forager With Communal Breeding and Helpers at the Nest. J Comp Psychol 118:37-47. https://doi.org/10.1037/0735-7036.118.1.37

Schradin C, Pillay N (2005b) Intraspecific Variation in the Spatial and Social Organization of the African Striped Mouse. J Mammal 86:99-107. https://doi.org/10.1644/15451542(2005)086<0099:IVITSA>2.0.CO;2 
Schradin C, Pillay N, Kondratyeva A, et al (2015) Basal blood glucose concentration in freeliving striped mice is influenced by food availability, ambient temperature and social tactic. Biol Lett 11:. https://doi.org/10.1098/rsbl.2015.0208

Schradin C, Scantlebury M, Pillay N, König B (2009a) Testosterone Levels in Dominant Sociable Males Are Lower than in Solitary Roamers: Physiological Differences between Three Male Reproductive Tactics in a Sociably Flexible Mammal. Am Nat 173:376-388. https://doi.org/10.1086/596535

Schradin C, Schneider C, Yuen CH (2009b) Age at puberty in male African striped mice: the impact of food, population density and the presence of the father. Funct Ecol 23:1004-1013. https://doi.org/10.1111/j.1365-2435.2009.01569.x

Schradin C, Yuen CH (2011) Hormone levels of male African striped mice change as they switch between alternative reproductive tactics. Horm Behav 60:676-680. https://doi.org/10.1016/j.yhbeh.2011.09.002

Sih A, Del Giudice M (2012) Linking behavioural syndromes and cognition: A behavioural ecology perspective. Philos. Trans. R. Soc. B Biol. Sci. 367:2762-2772

Smith C, Philips A, Reichard M (2015) Cognitive ability is heritable and predicts the success of an alternative mating tactic. Proc R Soc B Biol Sci 282:. https://doi.org/10.1098/rspb.2015.1046

Soha JA, Peters S, Anderson RC, et al (2019) Performance on tests of cognitive ability is not repeatable across years in a songbird. Anim Behav 158:281-288. https://doi.org/10.1016/j.anbehav.2019.09.020

Sol D, Lefebvre L, Rodríguez-Teijeiro JD (2005) Brain size, innovative propensity and migratory behaviour in temperate Palaearctic birds. Proc R Soc B Biol Sci 272:1433-1441. https://doi.org/10.1098/rspb.2005.3099

Team RC (2019) A language and environment for statistical computing. R Foundation for Statistical Computing, Vienna, Austria. https://www.r-project.org/.

Thornton A, Samson J (2012) Innovative problem solving in wild meerkats. Anim Behav 83:14591468. https://doi.org/10.1016/j.anbehav.2012.03.018

Wat KKY, Banks PB, McArthur C (2020) Linking animal personality to problem-solving performance in urban common brushtail possums. Anim Behav 162:35-45. https://doi.org/10.1016/j.anbehav.2020.01.013

Webster SJ, Lefebvre L (2001) Problem solving and neophobia in a columbiform-passeriform assemblage in Barbados. Anim Behav 62:23-32. https://doi.org/10.1006/anbe.2000.1725

Wikum DA, Shanholtzer GF (1978) Application of the Braun-Blanquet cover-abundance scale for vegetation analysis in land development studies. Environ Manage 2:323-329. https://doi.org/10.1007/BF01866672

Wolak ME (2012) Nadiv: An R package to create relatedness matrices for estimating non-additive genetic variances in animal models. Methods Ecol Evol 3:792-796. 
https://doi.org/10.1111/j.2041-210X.2012.00213.x

Yuen CH, Pillay N, Heinrichs M, et al (2015) Personality does not constrain social and behavioural flexibility in African striped mice. Behav Ecol Sociobiol 69:1237-1249.

751 https://doi.org/10.1007/s00265-015-1937-6

752

Zinner D, Wheeler BC (2012) Violence among our closest relatives-aggression in nonhuman primate societies. In: H. H. Kortüm, \& J. Heinze (Eds.), Aggression in humans and other primates: biology, psychology, sociology, De Gruyter. Berlin, Germany, pp 41-86

755

756

\section{Tables}

757

Table 1: Influence of intrinsic characteristics on the food extraction task (task 1) performance in 48 striped mice by separate univariate mixed models. The Akaike's Information Criterion (AIC), the 759 Likelihood Ratio Test statistics ( $\left.\chi^{2}\right)$, the denominator degrees of freedom (Df), and P values (LM and 760 GLM, bold values $\mathrm{P}<0.05)$ are shown.

761

\begin{tabular}{|c|c|c|c|c|}
\hline Variables & AIC & $\chi^{2}$ & Df & $\mathrm{P}$ \\
\hline Success (yes/no) & $\underline{42.13}$ & & & \\
\hline ART & & 0.78 & 2 & 0.678 \\
\hline year & & 0.55 & 1 & 0.457 \\
\hline Age & & 1.71 & 1 & 0.190 \\
\hline Body condition & & 1.79 & 1 & 0.181 \\
\hline ART*year & & 0.00 & 1 & 1.000 \\
\hline ART*Age & & 3.60 & 1 & 0.057 \\
\hline ART* Body condition & & 0.108 & 1 & 0.742 \\
\hline Total number of success (0-4 lids) & 91.37 & & & \\
\hline ART & & 0.90 & 2 & 0.635 \\
\hline year & & 1.00 & 1 & 0.315 \\
\hline Age & & 2.06 & 1 & 0.150 \\
\hline Body condition & & 2.95 & 1 & 0.085 \\
\hline ART*year & & 5.76 & 1 & 0.055 \\
\hline ART*Age & & 6.02 & 1 & 0.049 \\
\hline ART* Body condition & & 2.35 & 1 & 0.125 \\
\hline Latency of $1^{\text {st }}$ success lid opening & 26.49 & & & \\
\hline ART & & 0.92 & 2 & 0.467 \\
\hline year & & 3.19 & 1 & 0.149 \\
\hline Age & & 3.39 & 1 & 0.139 \\
\hline Body condition & & 0.04 & 1 & 0.843 \\
\hline ART*year & & 4.88 & 1 & 0.091 \\
\hline ART*Age & & 2.26 & 1 & 0.207 \\
\hline ART* Body condition & & 4.53 & 1 & 0.100 \\
\hline Latency of $2^{\text {nd }}$ success lid opening & 24.94 & & & \\
\hline ART & & 0.62 & 2 & 0.617 \\
\hline year & & 0.24 & 1 & 0.672 \\
\hline Age & & 0.44 & 1 & 0.576 \\
\hline Body condition & & 0.66 & 1 & 0.501 \\
\hline ART*year & & - & - & - \\
\hline ART*Age & & 1.57 & 1 & 0.336 \\
\hline ART* Body condition & & 0.91 & 1 & 0.441 \\
\hline Latency of $3^{\text {rd }}$ success lid opening & 19.5 & & & \\
\hline ART & & 1.53 & 2 & 0.496 \\
\hline year & & - & - & - \\
\hline
\end{tabular}




\begin{tabular}{|c|c|c|c|c|}
\hline Age & & - & - & - \\
\hline Body condition & & 0.49 & 1 & 0.612 \\
\hline ART*year & & - & - & - \\
\hline ART*Age & & - & - & - \\
\hline ART* Body condition & & - & - & - \\
\hline \multicolumn{5}{|l|}{ Latency of $4^{\text {th }}$ success lid opening } \\
\hline & & - & - & - \\
\hline Solving time $1^{\text {st }}$ success lid opening & 40.52 & & & \\
\hline ART & & 0.71 & 2 & 0.545 \\
\hline year & & 7.10 & 1 & 0.056 \\
\hline Age & & 8.15 & 1 & 0.046 \\
\hline Body condition & & 1.81 & 1 & 0.249 \\
\hline $\mathrm{ART}^{*}$ year & & 3.53 & 1 & 0.133 \\
\hline ART*Age & & 1.99 & 1 & 0.231 \\
\hline ART* Body condition & & 0.01 & 1 & 0.931 \\
\hline $\begin{array}{l}\text { Solving time of } 2^{\text {nd }} \text { success lid } \\
\text { opening }\end{array}$ & 45.04 & & & \\
\hline ART & & 0.05 & 2 & 0.947 \\
\hline year & & 0.04 & 1 & 0.853 \\
\hline Age & & 0.02 & 1 & 0.899 \\
\hline Body condition & & 0.01 & 1 & 0.937 \\
\hline ART*year & & - & - & - \\
\hline ART*Age & & 0.08 & 1 & 0.805 \\
\hline ART* Body condition & & 0.01 & 1 & 0.793 \\
\hline $\begin{array}{l}\text { Solving time of } 3^{\text {rd }} \text { success lid } \\
\text { opening }\end{array}$ & 8.77 & & & \\
\hline ART & & 0.02 & 2 & 0.982 \\
\hline year & & - & - & - \\
\hline Age & & - & - & - \\
\hline Body condition & & 0.77 & 1 & 0.540 \\
\hline $\mathrm{ART}^{*}$ year & & - & - & - \\
\hline ART*Age & & - & - & - \\
\hline ART* Body condition & & - & - & - \\
\hline \multicolumn{5}{|l|}{$\begin{array}{l}\text { Solving time of } 4^{\text {th }} \text { success lid } \\
\text { opening }\end{array}$} \\
\hline Time attempting to open the lids & 68.07 & & & \\
\hline ART & & 1.14 & 2 & 0.350 \\
\hline year & & 0.01 & 1 & 0.915 \\
\hline Age & & 0.14 & 1 & 0.716 \\
\hline Body condition & & 0.40 & 1 & 0.535 \\
\hline ART*year & & 2.19 & 1 & 0.162 \\
\hline ART*Age & & 1.79 & 1 & 0.204 \\
\hline ART* Body condition & & 1.46 & 1 & 0.249 \\
\hline
\end{tabular}

Table 2: Influence of intrinsic characteristics on the door opening task (task 2) performance in 41 striped 764 mice by separate univariate mixed models. Akaike's Information Criterion (AIC), the Likelihood Ratio 765 Test statistics $(\chi 2)$, the denominator degrees of freedom (Df), and P values (LM and GLM, bold values $766 \mathrm{P}<0.05)$ are shown.

767

\begin{tabular}{lcccc}
\hline Variables & AIC & $\chi^{2}$ & Df & P \\
\hline $\begin{array}{l}\text { Number of trials to reach 3 success } \\
\text { ART }\end{array}$ & 92.23 & & & \\
& & 0.30 & 2 & 0.858
\end{tabular}




\begin{tabular}{|c|c|c|c|c|}
\hline Year & & 0.02 & 1 & 0.897 \\
\hline Age & & 0.18 & 1 & 0.671 \\
\hline Body condition & & 0.06 & 1 & 0.799 \\
\hline ART*year & & 0.01 & 1 & 0.914 \\
\hline ART*Age & & 0.01 & 1 & 0.944 \\
\hline ART* Body condition & & 0.04 & 1 & 0.834 \\
\hline Latency of $1^{\text {st }}$ success & 52.19 & & & \\
\hline ART & & 2.61 & 2 & 0.114 \\
\hline Year & & 0.87 & 1 & 0.369 \\
\hline Age & & 5.66 & 1 & 0.035 \\
\hline Body condition & & 0.18 & 1 & 0.678 \\
\hline $\mathrm{ART}^{*}$ year & & 0.73 & 1 & 0.410 \\
\hline ART*Age & & 0.01 & 1 & 0.944 \\
\hline ART* Body condition & & 0.77 & 1 & 0.397 \\
\hline Latency of $2^{\text {nd }}$ success & 68.81 & & & \\
\hline ART & & 5.14 & 2 & 0.024 \\
\hline Year & & 1.20 & 1 & 0.294 \\
\hline Age & & 10.93 & 1 & 0.006 \\
\hline Body condition & & 0.02 & 1 & 0.879 \\
\hline $\mathrm{ART}^{*}$ year & & 0.11 & 1 & 0.742 \\
\hline ART*Age & & 0.41 & 1 & 0.532 \\
\hline ART* Body condition & & 0.07 & 1 & 0.794 \\
\hline Latency of $3^{\text {rd }}$ success & 93.40 & & & \\
\hline ART & & 0.62 & 2 & 0.553 \\
\hline Year & & 0.37 & 1 & 0.551 \\
\hline Age & & 0.12 & 1 & 0.738 \\
\hline Body condition & & 0.75 & 1 & 0.404 \\
\hline ART*year & & 0.91 & 1 & 0.359 \\
\hline ART*Age & & 0.34 & 1 & 0.568 \\
\hline ART* Body condition & & 0.83 & 1 & 0.379 \\
\hline
\end{tabular}

769

770

771

772

773

774

775

776

777

778

779

780

781

782

783

784

\section{Figure captions}

Figure 1 Relationship between personality traits: a) activity measured as percentage of time spent in movement during the open field test and exploration measured as the latency (in seconds) to first touch the novel problem-solving device; b) boldness measured as the total time (in seconds) an individual spent in the open part of the arena and exploration; c) boldness and activity. $* \mathrm{P}<0.05, * * \mathrm{P}<0.01$, (N $=48$, Spearman rank correlation).

Figure 2 Total number of trials to successfully open 1 to 4 lids according to ARTs $\left(\mathrm{N}_{\text {breeders }}=17\right.$, $\left.\mathrm{N}_{\text {philopatrics }}=8, \mathrm{~N}_{\text {roamers }}=23\right) . * \mathrm{P} \leq 0.05(\mathrm{~N}=48 ; \mathrm{LM})$. The box shows the first and third quartiles, the line is the median, the whiskers are $1.5 \mathrm{X}$ the difference between the third and first quartiles.

Figure 3 Relationship between striped mice age (in months) and the first solving time (in seconds) in the food extraction task and $* \mathrm{P}<0.05(\mathrm{~N}=27, \mathrm{LM})$. 
785 Figure 4 Relationship between striped mice age (in months) and the latency (in seconds) to open the 786 door for the first time. * $\mathrm{P}<0.05(\mathrm{~N}=41, \mathrm{LM})$.

787

788 